\title{
Prokrastinasi dan Pola Tidur Mahasiswa
}

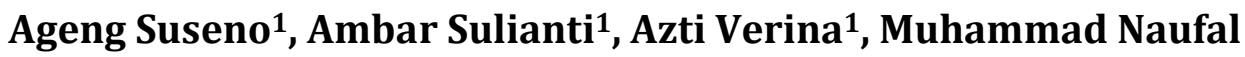 \\ Fadlurrahman Riyadhi \\ 1Fakultas Psikologi UIN Sunan Gunung Djati Bandung \\ 2SMA N 9 Bandung
}

DOI: http://doi.org/10.29080/jpp.v11i2.454

\begin{abstract}
Although college students are having a transition to adulthood in their development, they were reported frequently have academic procrastination. This research aims to analyze the impact of academic procrastination on sleep pattern of college student. The method used is a non-experimental quantitative study with a cross-sectional model. Having non-probability techniques sampling, there were 300 students involved. The results showed that there was an effect of academic procrastination on sleep patterns which is the time of wake-up and sleep hours on holidays $(p<0.05)$. The highest procrastination among students was planning to actual performance. Considering procrastination has a bad impact on health, it is recommended that students practicing discipline in doing assignments and making list priorities.
\end{abstract}

Keywords : Academic Procrastination, Sleep Patterns, Students

\begin{abstract}
Abstrak : Meskipun mahasiswa dalam perkembangan psikologi berada dalam peralihan menuju dewasa, namun mereka dilaporkan sering melakukan prokrastinasi akademik. Penelitian ini bertujuan menganalisis dampak prokrastinasi akademik pada pola tidur mahasiswa. Metode yang digunakan ialah studi kuantitatif non-eksperimen dengan model cross-sectional. Bertindak sebagai subjek penelitian ialah 300 mahasiswa yang diambil melalui Teknik non probability sampling. Hasil penelitian ini menunjukkan terdapat pengaruh prokrastinasi akademik terhadap pola tidur yaitu pada jam bangun pagi dan jam tidur di hari libur $(\mathrm{p}<0.05)$. Kebiasaan prokrastinasi tertinggi pada mahasiswa yaitu pada kesenjangan waktu antara rencana dan kinerja aktual. Mengingat kebiasaan prokrastinasi berdampak buruk pada kesehatan, disarankan mahasiswa untuk melatih kedisiplinan untuk dapat mengerjakan tugas sesuai dengan rencana yang telah mereka buat dan mengerjakan sesuai prioritas.
\end{abstract}

Kata kunci : Prokrastinasi Akademik, Pola Tidur, Mahasiswa 


\section{Pendahuluan}

Prokrastinasi akademik adalah perilaku menunda-nunda dalam menyelesaikan tugas akademik yang ada karena alasan yang tidak rasional (Yazıcı \& Bulut, 2015). Motivasi siswa yang lemah menjadi penyebab perilaku prokrastinasi di dalam akademik (Grunschel, Schwinger, Steinmayr, \& Fries, 2016). Prokrastinasi akademik seringkali berbentuk penundaan tugas akademik karena keinginan sendiri (Gustavson \& Miyake, 2017). Perilaku menunda tugas-tugas akademik tentunya berdampak pada kemajuan akademis yang menjadi terhambat (Zakeri, Esfahani, \& Razmjoee, 2013). Prokrastinasi akademik membuat kinerja menjadi tidak optimal dan menghasilkan keadaan tekanan psikologis (Qun G. Jiao, Denise A. DaRos-Voseles, Kathleen M. T. Collins, 2011). Prokrastinasi akademik juga menimbulkan banyak keterlambatan karena menunda tugastugas akademik dengan alasan yang irasional (Corkin, Yu, Wolters, \& Wiesner, 2014).

Penelitian di Amerika menunjukkan bahwa prokrastinasi akademik terjadi pada 70-95\% mahasiswa. Penelitian di Fakultas Psikologi Universitas Surabaya menunjukkan 95\% mahasiswa pernah melakukan prokrastinasi akademik dengan dua alasan utama yaitu merasa malas mengerjakan tugas dan karena ada banyaknya tugas lain. yang harus dilakukan (Kartadinata, I \& Tjundjing, 2007). Dampak prokrastinasi terhadap kesehatan telah banyak dilaporkan. Prokrastinasi akademik merupakan hal merugikan yang perlu ditanggapi secara serius bagi mahasiswa karena banyaknya frekuensi tenggat waktu yang dihadapi. Berbagai penelitian menunjukkan prokrastinasi akademik menyebabkan lumpuhnya kemajuan akademik yang dapat dilihat dari menurunnya nilai akademik dan menurunnya rata-rata kondisi kesehatan secara keseluruhan prokrastinasi dapat menurunkan kualitas mahasiswa. Prokrastinasi akademik merupakan siklus jahat yang dapat meningkatkan tekanan waktu apabila seorang procrastinator sukses melakukan provokasi nasi maka dia akan cenderung melakukan prokrastinasi selanjutnya (Kartadinata, I \& Tjundjing, 2007).

Dewasa ini, para mahasiswa sering menemukan masalah dalam belajar yang mungkin karena terlena oleh canggihnya teknologi (permainan dawai pada HP). Masalah belajar terdiri dari keterlambatan akademik, ketercepatan dalam belajar, sangat lambat dalam belajar, kurang motivasi dalam belajar, bersikap dan kebiasaan buruk dalam belajar (Prayitno, 2004). Akibat hal tersebut, banyak pelajar yang tidak dapat membagi waktu dengan baik mana yang harus diprioritaskan dan mana yang tidak sehingga mereka tidak bisa memilah tugas-tugasnya. Dalam pengaturan manajemen waktu yang tidak tepat dapat terjadi suatu kelalaian dalam menyelesaikan tugas. Kondisi seperti ini menandakan adanya suatu penundaan dalam mengerjakan atau menyelesaikan tugas yang dikenal dengan Prokrastinasi akademik.

Kebiasaan prokrastinasi memunculkan pola tidur yang tidak sehat, memicu depresi, stress, dan berbagai penyimpangan psikologis lainnya Pola tidur yang terganggu menyebabkan kurang tidur. Sebagai konsekuensi dari kurang tidur berdampak pada kesehatan fisik dan mental remaja. Studi berbasis klinik pada remaja telah menunjukkan hubungan yang kuat antara pembatasan tidur kronis dan kecemasan, depresi, dan nyeri somatic. Remaja yang tidur lebih pendek juga menunjukkan penurunan dalam kinerja akademik dan peningkatan perilaku risiko penggunaan narkoba dan mengemudi mengantuk. Gangguan tidur pada remaja meningkatkan risiko penurunan berikutnya dalam kesehatan sosial, psikologis, fisik, dan mental (Lund, Reider, Whiting, \& Prichard, 2010).

Kualitas tidur pada remaja yang buruk berdampak bagi kesehatan seperti hipertensi pulmonal dan penurunan fungsi pernapasan (Shakkottai, O'Brien, Nasr, \& Chervin, 2018). Kurang tidur pada remaja dapat berdampak buruk dalam aktivitas belajar di siang hari (Mah, Kezirian, Marcello, \& Dement, 2018). Kebiasaan tidur yang buruk pada remaja juga bisa berdampak pada kinerja akademik mahasiswa (Barone, 2017). Pola tidur 
yang buruk pada remaja akan berdampak kepada penurunan kinerja akademik dan membuat siswa menjadi malas (Foss, Smith, \& O'Brien, 2019). Pola tidur yang buruk pada remaja berdampak pada aktivitas fisik yang dan menggangu aktivitas lainnya (Verkooijen et al., 2018).

Beberapa penelitian menunjukkan bahwa kurang tidur memiliki efek buruk terhadap kesehatan seperti gangguan kardiovaskular, kekebalan tubuh, metabolisme, dan endokrin (Jung et al., 2018). Selain itu dampak fisiologis dari kurang tidur adalah gangguan fungsi kekebalan tubuh, kesehatan, dan metabolisme glukosa (Frenda \& Fenn, 2016). Kurang tidur juga mempengaruhi proses pembelajaran dan memori karena pembentukan memori tergantung pada kondisi tidur (Chen \& Chen, 2019). Kurang tidur merusak pusat memori dan belajar pada hippocampus, berbagai mekanisme termasuk rangsangan saraf, plastase sinaptik, dan penurunan neurogenesis (Cui et al., 2019). Menurunnya memori non-kontekstual dan timbulnya emosional yang tidak terkendali juga merupakan dampak dari kurang tidur (Tempesta et al., 2016). Zhong dkk mempelajari 18 orang dewasa yang sehat dan menemukan bahwa detak jantung, komponen frekuensi rendah dari variabilitas detak jantung, dan variabilitas tekanan darah semua meningkat, sementara sensitivitas baroreflex menurun (Yuan, Wang, \& Guo, 2016).

Hingga saat ini belum dilaporkan di Indonesia bagaimana dampak prokrastinasi akademik terhadap pola tidur pada. Penelitian ini bertujuan untuk menganalisis item-item pola tidur mana saja terkena dampak dari prokrastinasi akademik mahasiswa. Pengaruh prokrastinasi akan dilihat dampaknya pada waktu tidur malam hari, durasi tidur, waktu bangun tidur, kebiasaan bangun di tengah tidur malam, dan kebiasaan tidur siang.

\section{Metode Penelitian}

Penelitian ini menggunakan pendekatan kuantitatif yang bertujuan menguji teori secara objektif dengan cara memeriksa atau meneliti hubungan antar variabel-variabel. Subjek yang diambil dalam penelitian ini adalah pelajar remaja akhir yaitu mahasiswa sejumlah 300 orang. Pengambilan subjek menggunakan non probability teknik samping. Kriteria subjek penelitian ialah mahasiswa yang pernah melakukan prokrastinasi akademik berdasarkan hasil survey. Prokrastinasi akademik diungkap dengan menggunakan skala prokrastinasi akademik. Semakin tinggi skor yang diperoleh berarti semakin sering subjek melakukan prokrastinasi akademik. Sebaliknya, semakin rendah skor berarti semakin jarang subjek melakukan prokrastinasi akademik. Berdasarkan definisi operasional ini disusun indikator-indikator dari variabel prokrastinasi akademik yang terdiri dari belajar menghadapi ujian, tugas kuliah, menghadiri pertemuan, dan tugas administratif.

Dalam mengambil data, peneliti menyebar kuesioner kepada subjek menggunakan media google form. Pada form pertama, subjek diberi petunjuk pengisian berupa kuesioner memakai skala Likert dengan skala 1-5 (bila mendekati angka 1 menandakan bahwa subjek sangat tidak setuju dengan pernyataan dan bila mendekati angka 5 menandakan bahwa subjek sangat setuju dengan pernyataan). Pada form kedua, subjek diberi petunjuk pengisian dengan memilih pilihan berupa ya atau tidak. Kuesioner pola tidur dikembangkan dari buku tentang tidur dan berbagai hasil penelitian (Deliens et al., 2015; Gupta et al., 2008; Kim, Noh, Kim, \& Kwon, 2019) yang terdiri atas pertanyaan jam mulai tidur malam hari kerja dan hari libur, jam bangun pagi hari kerja dan hari libur, kebiasaan tidur tengah malam, kebiasaan tidur siang. Hal ini bertujuan menangkap semua parameter dasar yang terkait dengan tidur. Kuesioner ini berisi pertanyaan yang terkait dengan data demografis dan parameter tidur. Studi ini menilai kebiasaan tidur pada parameter yang berbeda misalnya, total durasi tidur dalam sehari, waktu tidur malam (hari kerja dan hari libur), waktu bangun tidur, kebisaan tidur siang (Lund et al., 2010). 


\section{Hasil Penelitian}

Berdasarkan pengambilan data prokrastinasi, terdapat perbedaan kebiasaan prokrastinasi dari keempat dimensi yang diteliti, diperlihatkan pada gambar 1.

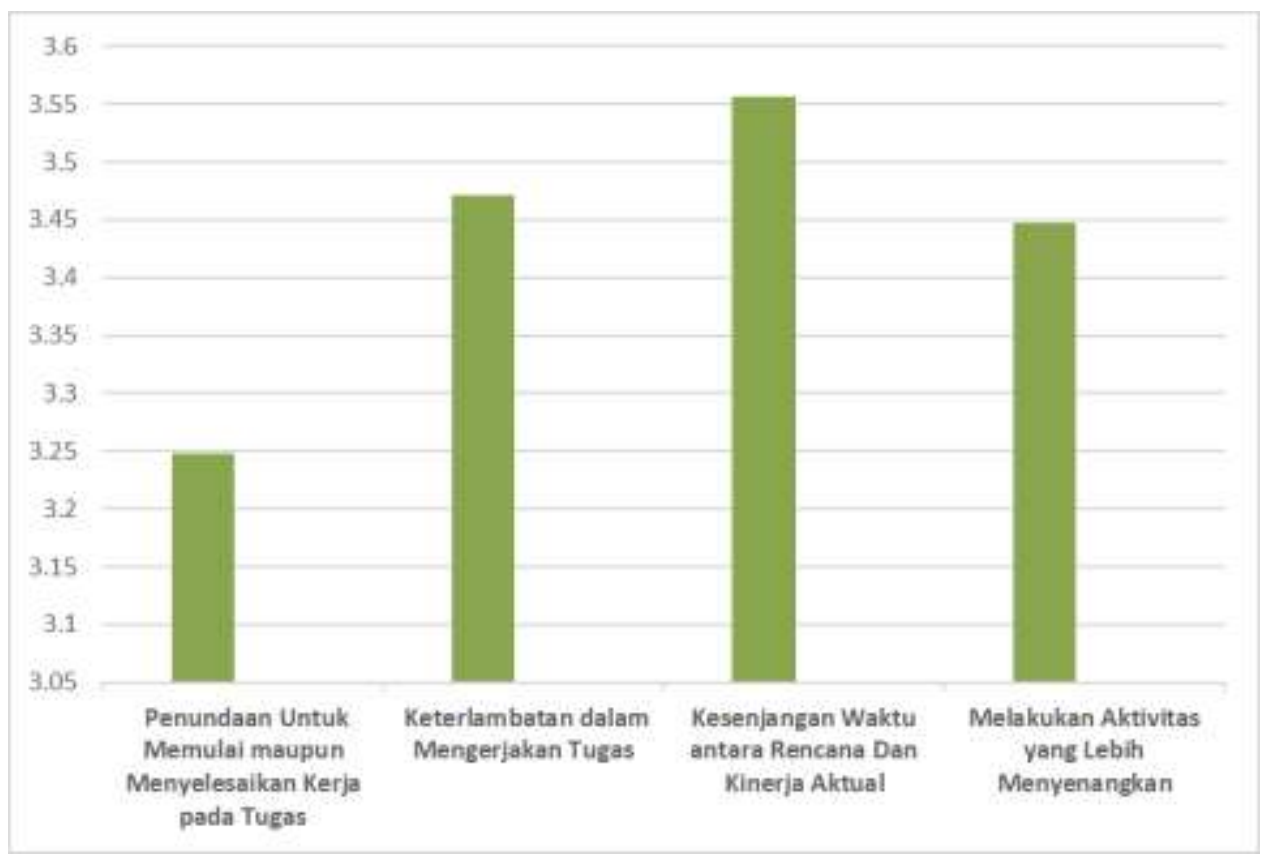

\section{Gambar 1. Karakteristik Prokrastinasi pada Mahasiswa}

Gambar 1 memperlihatkan kebiasaan prokrastinasi tertinggi pada mahasiswa yaitu pada kesenjangan waktu antara rencana dan kinerja actual. Adapun kebiasaan prokrastinasi terendah yaitu pada penundaan untuk memulai maupun menyelesaikan kerja pada tugas.

Hasil prokrastinasi ini kemudian dikelompokkan menurut kebiasaan prokrastinasi kelompok rendah, sedang dan tinggi. Masing-masing kelompok dinilai pola tidurnya, ditampilkan pada gambar 2 .

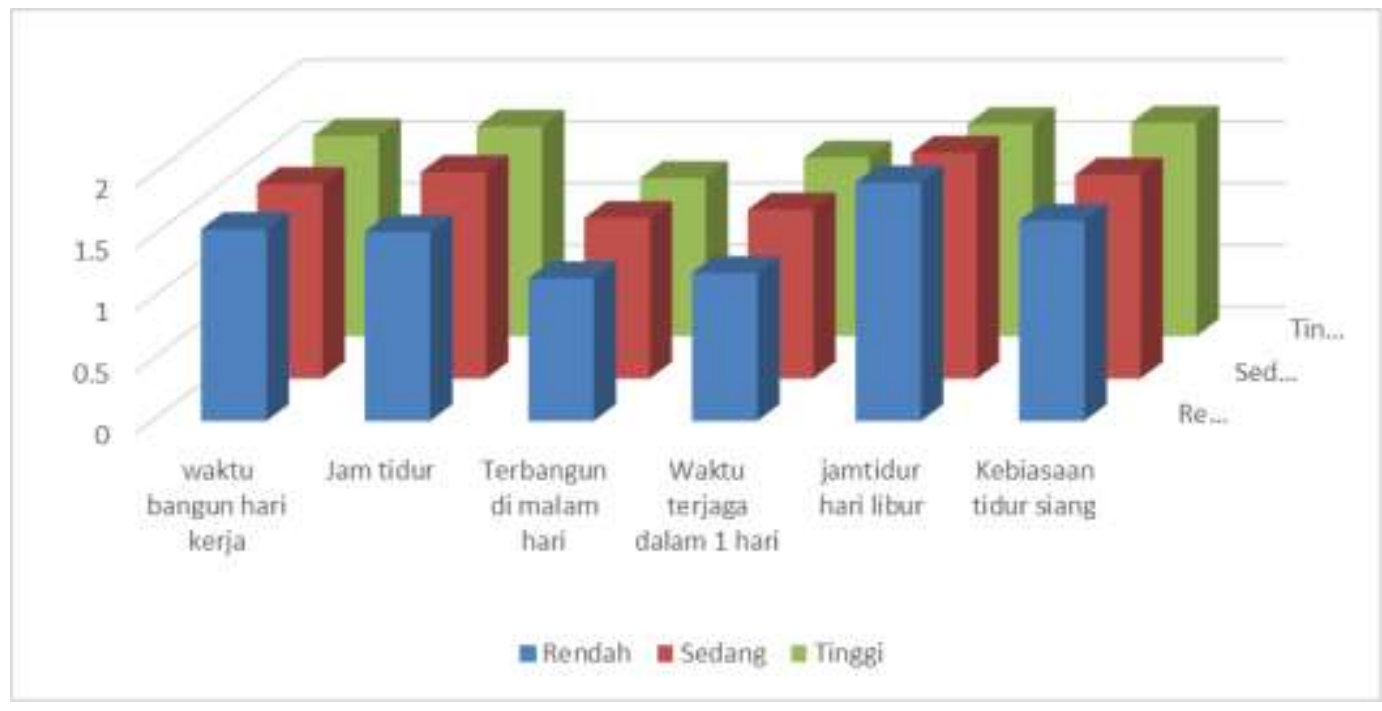

Gambar2. Grafik Sebaran Pola Tidur pada Kelompok Prokrastinasi 
Gambar 2 memperlihatkan adanya variasi pada pola tidur kelompok prokrastinasi rendah, sedang, dan tinggi. Untuk melihat pola tidur mana yang berbeda signifikan dilakukan analisis statistik Kruskal walls yang diperlihatkan pada tabel 1.

Tabel 1

Analisis Kuskal Walls

\begin{tabular}{lcccccc}
\hline $\begin{array}{l}\text { Test Kruskal } \\
\text { Wallis }\end{array}$ & $\begin{array}{c}\text { Jam tidur } \\
\text { hari kerja }\end{array}$ & $\begin{array}{c}\text { Jam tidur } \\
\text { malam }\end{array}$ & $\begin{array}{c}\text { Terbangun } \\
\text { malam }\end{array}$ & $\begin{array}{c}\text { Waktu } \\
\text { terjaga }\end{array}$ & $\begin{array}{c}\text { Jam tidur } \\
\text { hari libur }\end{array}$ & $\begin{array}{c}\text { Kebiasaan } \\
\text { tidur siang }\end{array}$ \\
\hline Chi-Square & 0.789 & 3.938 & 3.362 & 7.406 & 10.029 & 2.156 \\
\hline df & 2 & 2 & 2 & 2 & 2 & 2 \\
\hline Asymp. Sig. & 0.674 & 0.140 & 0.186 & 0.025 & 0.007 & 0.340 \\
\hline
\end{tabular}

Tabel 1 memperlihatkan bahwa terdapat perbedaan pola tidur yang berbeda signifikan pada jam bangun $(\mathrm{p}=0.025)$ dan jam tidur malam pada saat liburan $(\mathrm{p}=0.07)$. Karakteristeik pola tidur diperlihatkan pada tabel 2.

Tabel 2.

Pola Tidur pada Berbagai Kelompok Prokrastinasi

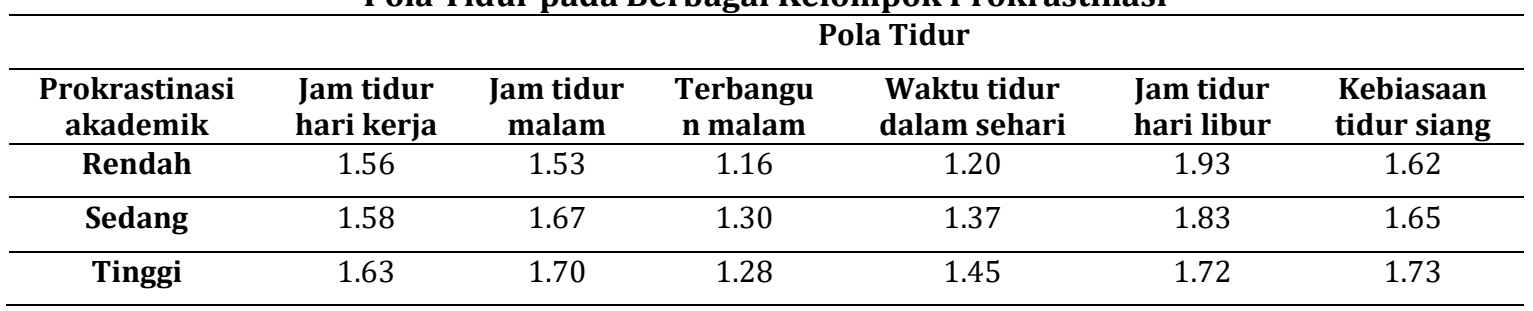

Keterangan:

Waktu tidur malam sehari-hari (mendekati angka 2 berari lebih dari pk 23.00)

Durasi tidur malam (mendekati angka 2 berarti waktu tidur semakin sedikit)

Bangun tengah malam (mendekati angka 1 berarti tidak dilakukan)

Bangun tidur pagi (mendekati angka 2 berarti bangun semakin siang)

Waktu tidur malam hari libur (mendekati angka 2 berari lebih dari pk 23.00)

Kebiasaan tidur siang (mendekati angka 2 berarti biasa tidur siang)

Pada tabel 2 terlihat bahwa untuk jumlah jam tidur, semakit tinggi prokrastinasi, semakin siang jam bangun tidur. Untuk jam tidur pada hari libur, ternyata semakin rendah prokrastinasi semakin malam waktu tidur di hari libur. Untuk melihat deskripsi persentase untuk waktu tidkur dan jam tidur malam di hari libur diperlihatkan pada tabel 3.

Tabel 3.

Persentasi Kebiasaan Waktu Tidur Malam di Hari Libur

\begin{tabular}{|c|c|c|c|}
\hline & & \multicolumn{2}{|c|}{ Jam Tidur Hari Libur } \\
\hline & & Frekuensi & Persentase \\
\hline Sebelum pk 23.00 & 57 & 19 & \\
\hline Pk 23.00 atau lebih & & 243 & 81 \\
\hline Total & & 300 & 100 \\
\hline
\end{tabular}

Tabel 3 menunjukkan bahwa 19\% responden melakukan tidur di bawah pukul 23 malam dan sebagian besar (81\%) responden biasa tidur jam 23 malam ke atas di hari libur. 


\section{Pembahasan}

Temuan pertama pada hasil penelitian ini menunjukkan tidak ada perbedaan yang signifikan antara kelompok mahasiswa yang melakukan prokrastinasi akademik rendah, sedang, dan tinggi terhadap jam tidur di hari kerja. Semua kelompok prokrastinasi ini tidur biasa tidur pada jam di atas 10 malam. Perbedaanya terletak pada urutan pengerjaan prioritas. Pada kelompok yang melakukan prokrastinasi tingkat rendah, mereka menunda waktu pengerjaan tugas hingga sore baru kemudian mengerjakan tugas. Selesai mengerjakan tugas mereka melakukan kegiatan online seperti menggunakan media social HP untuk bercengkerama dengan teman-temannya atau streaming di HP hingga malam hari baru tidur. Adapun orang dengan prokrastinasi akademik prokrastinasi akademik yang tinggi menunda tugas hingga malam dan mengerjakannya tepat sebelum tidur.

Temuan kedua dari hasil penelitian ini yaitu tidak terdapat perbedaan yang signifikan pada jumlah jam tidur malam baik kelompok prokrastinasi yang rendah, sedang, dan tinggi dalam durasi tidur malam. Mereka semua memiliki jam tidur malam yang kurang dari usia yang dibutuhkan pada remaja (kurang dari 7 jam). Hal ini dapat dijelaskan dengan mengaitkan kepada temuan pertama, yang mana jam tidur yang laut malam pada selua kelompok prokrastinasi menyebabkan durasi tidur malam yang memendek.

Temuan yang ketiga menunjukkan tidak ada perbedaan yang signifikan dalam kebiasaan bangun malam pada kelompok prokrastinasi rendah, sedang, dan tinggi. Semua kelompok jarang bangun di malam hari. Berbeda dengan prokrastinasi yang dilakukan oleh orang dewasa akhir, pada remaja akhir prokrastinasi yang dilakukan tidak mengganggu tidur mereka dan jarang menyebabkan mereka terbangun pada waktu pertengahan tidur.

Temuan keempat menunjukkan terdapat perbedaan yang signifikan pada jam bangun tidur pagi. Semakin tinggi prokrastinasi akademik yang dilakukan semakin siang bangun nya. Hal ini disebabkan karena mahasiswa yang melakukan prokrastinasi akademik yang tinggi, tidur dalam kondisi pikiran terbebani. Ketika tidur, otak tidak akan berhenti bekerja, bahkan faktanya para ahli saraf telah menunjukkan bahwa beberapa area otak sebenarnya lebih aktif selama keadaan tidur daripada saat bangun. Tidur berfungsi dalam pemulihan, konsolidasi memori, dan fungsi kognitif. Hal ini berpengaruh pada semangat ketika mahasiswa bangun pagi, sehingga mereka bermalas-malasan untuk bangun dan bangun lebih siang.

McKenna dkk mengemukakan dalam buku 'Sleep Disorder Medicine' menyatakan bahwa bahwaa agar pusat tidur mendominasi pusat kewaspadaan, kita harus lelah, tenang dan santai, otak kita tidak aktif dan lingkungan yang tenang dan gelap, yang nyaman dan suhu yang tepat. Ini adalah prasyarat tidur. Stimulus eksternal seperti kebisingan, cahaya dan kekhawatiran, mengaktifkan pusat kewaspadaan otak dan mencegah untuk tidur. Proses tidur terjadi dalam lima tahap, empat pertama membentuk tidur Non-Rapid Eye Movement (NREM) sebagai fungsi restoratif - dan yang kelima adalah tidur Rapid Eye Movement (REM) yang untuk pemrosesan kognitif dan bermimpi (McKenna et al, 2017). Menunda-nunda tugas akademik menyebabkan penyelesaian tugas dilakukan sebelum tidur. Hal ini membuat otak berpikir saat harus beristirahat. Hal ini menyebabkan otak lelah ketika waktu bangun tiba. Mahasiswa dengan prokrastinasi tinggi menjadi malas untuk bangun pagi.

Temuan kelima pada hasil penelitian ini menunjukkan terdapat pengaruh prokrastinasi pada jam tidur malam ketika hari libur. Semakin tinggi prokasinasi akademik, semakin malam subjek tidur. Responden dengan prokrastinasi tinggi, melakukan aktivitas kegembiraan dengan smartphone-nya hingga larut malam di hari libur. Prokrastinasi akademik merupakan siklus buruk yang dapat meningkatkan tekanan waktu apabila seorang procrastinator sukses melakukan prokrastinasi maka dia akan 
cenderung melakukan prokrastinasi selanjutnya (Kartadinata, I \& Tjundjing, 2007). Hal tersebut merupakan hal yang buruk yang dapat menjadi kebiasaan. Menurut Nagasaka (dalam Ferrari, 2007) menunjukkan bahwa penundaan, terjadi karena pengendalian negative yang mempengaruhi, pengaruh di masa lalu. Karena mahasiswa terbiasa menunda-nunda jam tidur malam, sewaktu liburan, mereka terbiasa menunda jam tidur malam.

Temuan keenam dari penelitian ini, baik kelompok prokrastinasi akademik rendah, sedang, maupun tinggi, sama-sama memiliki kebiasaan tidur siang. Hal ini mereka lakukan pada jam istirahat dan ada juga yang melakukannya saat perkuliahan siang. Hal ini terjadi karena baik prokrastinasi rendah, sedang, dan tinggi sama-sama terbiasa tidur malam hari, sehingga merasa lesu dan mengantuk di siang hari.

\section{Simpulan dan Saran}

Teknik Hasil penelitian ini menunjukkan terdapat pengaruh prokrastinasi akademik terhadap pola tidur yaitu pada jam bangun pagi dan jam tidur di hari libur. Mengingat kebiasaan prokrastinasi berdampak buruk pada kesehatan, disarankan mahasiswa untuk melatih kedisiplinan untuk dapat mengerjakan tugas sesuai dengan rencana yang telah mereka buat dan mengerjakan sesuai prioritas. Saran untuk penelitian selanjutnya adalah agar dilakukan penelitian hubungan prokrastinasi akademik dengan lima tahapan tidur dengan mengamati Rapid eye movement.

\section{Daftar Pustaka}

Anggawijaya, S. (2013). Hubungan Antara Depresi Dan Prokrastinasi Akademik, Caliyptra 2(2), 1-12.

Barone, T. L. (2017). "Sleep is on the back burner": Working students and sleep. Social Science Journal, 54(2), 159-167. https://doi.org/10.1016/j.soscij.2016.12.001

Broadbent, L. (2018). Sleep: A basic introduction into the neuroscience of sleep and the effects of sleep deprivation on health, safety and wellbeing. Gradiosh Dipnebosh.

Chen, W. L., \& Chen, J. H. (2019). Consequences of inadequate sleep during the college years: Sleep deprivation, grade point average, and college graduation. Preventive Medicine, 124(September 2018), 23-28. https://doi.org/10.1016/j.ypmed.2019.04.017

Corkin, D. M., Yu, S. L., Wolters, C. A., \& Wiesner, M. (2014). The role of the college classroom climate on academic procrastination. Learning and Individual Differences, 32, 294-303. https://doi.org/10.1016/j.lindif.2014.04.001

Cui, L., Xue, R., Zhang, X., Chen, S., Wan, Y., \& Wu, W. (2019). Sleep deprivation inhibits proliferation of adult hippocampal neural progenitor cells by a mechanism involving IL-17 and p38 MAPK. Brain Research, 1714(January), 81-87. https://doi.org/10.1016/j.brainres.2019.01.024

Deliens, G., Stercq, F., Mary, A., Slama, H., Cleeremans, A., Peigneux, P., \& Kissine, M. (2015). Impact of Acute Sleep Deprivation On Sarcasm Detection. Plos One, 10(11), 1-19. Https://Doi.Org/10.1371/Journal.Pone.0140527

Eckert, M., Ebert, D. D., Lehr, D., Sieland, B., \& Berking, M. (2016). Overcome procrastination: Enhancing emotion regulation skills reduce procrastination. Learning and Individual Differences, 52, 10-18. https://doi.org/10.1016/j.lindif.2016.10.001

Fauziah, H. H. (2019.). Fakor-Faktor Yang Mempengaruhi Prokrastinasi Akademik Pada Mahasiswa Fakultas Psikologi Uin Sunan Gunung Djati Bandung, Psymphatic(105).

Fernie, B. A., Kopar, U. Y., Fisher, P. L., \& Spada, M. M. (2018). Further development and testing of the metacognitive model of procrastination: Self-reported academic 
performance. Journal of Affective Disorders, 240 (November 2017), 1-5. https://doi.org/10.1016/j.jad.2018.07.018

Foss, R. D., Smith, R. L., \& O'Brien, N. P. (2019). School start times and teenage driver motor vehicle crashes. Accident Analysis and Prevention, 126(February 2018), 54-63. https://doi.org/10.1016/j.aap.2018.03.031

Frenda, S. J., \& Fenn, K. M. (2016). Sleep Less, Think Worse: The Effect of Sleep Deprivation on Working Memory. Journal of Applied Research in Memory and Cognition, 5(4), 463-469. https://doi.org/10.1016/j.jarmac.2016.10.001

Grunschel, C., Schwinger, M., Steinmayr, R., \& Fries, S. (2016). Effects of using motivational regulation strategies on students' academic procrastination, academic performance, and well-being. Learning and Individual Differences, 49, 162-170. https://doi.org/10.1016/j.lindif.2016.06.008

Gupta, R., Bhatia, M. S., Chhabra, V., Sharma, S., Dahiya, D., Semalti, K., ... Dua, R. S. (2008). Sleep Patterns of Urban School-Going Adolescents. Indian Pediatrics, 45(3), 183-189.

Gustavson, D. E., \& Miyake, A. (2017). Academic procrastination and goal accomplishment: A combined experimental and individual differences investigation. Learning and Individual Differences, 54,160-172. https://doi.org/10.1016/j.lindif.2017.01.010

Harsono. 2007. Kapita Selekta Neurologi. Gadjah Mada University Press. Edisi Ke 7. Yogyakarta

Hernández, C., Rivera, D., Moessner, M., \& Crosby, R. D. (2019). Computers in Human Behavior Depressed and swiping my problems for later: The moderation e ff ect between procrastination and depressive symptomatology on internet addiction. Computers in Human Behavior, 97(February), 1-9. https://doi.org/10.1016/j.chb.2019.02.027

Jung, J. H., Kim, M., Lee, S. J., Lee, E., Lee, S. A., Lee, J. D., ... Kim, B. G. (2018). Effect of sleep deprivation on hearing levels in rats. International Journal of Pediatric Otorhinolaryngology,
https://doi.org/10.1016/j.j.ijporl.2018.07.003

169-175.

Kartadinata, I \& Tjundjing, S. (2007). I Love You Tomorrow: Prokrastinasi Akademik Dan Manajemen Waktu. Jurnal Anima, 23(2), 109-119. Retrieved from Http://Repository.Ubaya.Ac.Id/23843/1/V_023_N_002_A_002.Pdf

Kim, J., Noh, J. W., Kim, A., \& Kwon, Y. D. (2019). Relationships Between Sleep Patterns, Health Risk Behaviors, And Health Outcomes Among School-Based Population of Adolescents: A Panel Analysis of The Korean Children and Youth Panel Survey. International Journal of Environmental Research and Public Health, 16(13). Https://Doi.Org/10.3390/Ijerph16132278

Kljajic, K., \& Gaudreau, P. (2018). Does it matter if students procrastinate more in some courses than in others? A multilevel perspective on procrastination and academic achievement. Learning and Instruction, 58(February), 193-200. https://doi.org/10.1016/j.learninstruc.2018.06.005

Küchler, A. M., Albus, P., Ebert, D. D., \& Baumeister, H. (2019). Effectiveness of an internetbased intervention for procrastination in college students (StudiCare Procrastination): Study protocol of a randomized controlled trial. Internet $\begin{array}{lll}\text { Interventions, } & 100245 .\end{array}$ https://doi.org/10.1016/j.invent.2019.100245

Kusuma, L. W. A. (2010). Kecenderungan Perilaku Prokrastinasi Akademik Pada Mahasiswa Fakultas Psikologi Universitas Sanata Dharma Yogyakarta. Universitas Sanata Dharma.

Lund, H. G., Reider, B. D., Whiting, A. B., \& Prichard, J. R. (2010). Sleep Patterns and Predictors of Disturbed Sleep In A Large Population Of College Students. Journal of Adolescent Health, 46(2), 124-132. Https://Doi.Org/10.1016/J.Jadohealth.2009.06.016 
Mah, C. D., Kezirian, E. J., Marcello, B. M., \& Dement, W. C. (2018). Poor sleep quality and insufficient sleep of a collegiate student-athlete population. Sleep Health, 4(3), 251257. https://doi.org/10.1016/j.sleh.2018.02.005

Meier, A., Reinecke, L., \& Meltzer, C. E. (2016). Facebocrastination? Predictors of using Facebook for procrastination and its effects on students' well-being. Computers in Human Behavior, 64, 65-76. https://doi.org/10.1016/j.chb.2016.06.011.

McKenna, J. T., Zielinski, M. R., \& McCarley, R. W. (2017). Neurobiology of REM Sleep, NREM Sleep Homeostasis, and Gamma Band Oscillations. In S. Chokroverty (Ed.), Sleep Disorders Medicine (4th ed., Vol. 32, Issue 9, pp. 55-78). Springer. https://doi.org/10.1093/sleep/18.9.731.

Potter \& Perry. (2005). Buku Ajar Fundamental Keperawatan Konsep, Proses, Dan Praktik. Edisi 4 Volume 1. EGC. Jakarta

Qun G. Jiao, Denise A. DaRos-Voseles, Kathleen M. T. Collins, and A. J. O. (2011). Academic procrastination and the performance of graduate-level cooperative groups in research methods courses. Journal of the Scholarship of Teaching and Learning 11(1), 119-138.

Rebetez, M. M. L., Rochat, L., Barsics, C., \& Van der Linden, M. (2016). Procrastination as a self-regulation failure: The role of inhibition, negative affect, and gender. Personality and Individual Differences, 101, 435-439. https://doi.org/10.1016/j.paid.2016.06.049

Shakkottai, A., O’Brien, L. M., Nasr, S. Z., \& Chervin, R. D. (2018). Sleep disturbances and their impact in pediatric cystic fibrosis. Sleep Medicine Reviews, 42, 100-110. https://doi.org/10.1016/j.smrv.2018.07.002

Srantih, T. (1980). Pengaruh Perfeksionisme Terhadap Prokrastinasi Akademik Pada Mahasiswa Yang Sedang Mengerjakan Skripsi Di Fakultas Psikologi Uin Sunan Gunung Djati Bandung.

Supratiknya, A. (2015). Metodologi Penelitian Kuantitatif \& Kualitatif. Yogyakarta : Universitas Sanata Dharma.

Suwarna, A. H., Pendidikan, W., Fik, R., Abstrak, U. N. Y., Sahid, T., Yogyakarta, R., ... Yogyakarta, R. (2013). Perbedaan Pola Tidur Antara Kelompok Terlatih Dan Tidak Terlatih, 85-96.

Tempesta, D., Socci, V., Coppo, M., Dello Ioio, G., Nepa, V., De Gennaro, L., \& Ferrara, M. (2016). The effect of sleep deprivation on the encoding of contextual and noncontextual aspects of emotional memory. Neurobiology of Learning and Memory, 131, 9-17. https://doi.org/10.1016/j.nlm.2016.03.007

Ulum, M. I., \& Indonesia, U. P. (N.D.). Strategi Self-Regulated Learning Untuk Menurunkan, (229), 153-169.

Verkooijen, S., de Vos, N., Bakker-Camu, B. J. W., Branje, S. J. T., Kahn, R. S., Ophoff, R. A., Boks, M. P. M. (2018). Sleep Disturbances, Psychosocial Difficulties, and Health Risk Behavior in 16,781 Dutch Adolescents. Academic Pediatrics, 18(6), 655-661. https://doi.org/10.1016/j.acap.2018.03.003

Wicaksono, D. W., Yusuf, A., \& Widyawati, I. Y. (2009). Faktor Dominan Yang Berhubungan Dengan Kualitas Tidur Pada Mahasiswa Fakultas Keperawatan

Widodo, D. P., \& Soetomenggolo, T. S. (2000). Perkembangan Normal Tidur Pada Anak Dan Kelainannya. Sari Pediatri, 2(3), 2-8.

Yazıcı, H., \& Bulut, R. (2015). Investigation into the Academic Procrastination of Teacher Candidates' Social Studies with Regard to their Personality Traits1. Procedia-Social and Behavioral Sciences, 174, 2270-2277. https://doi.org/10.1016/j.sbspro.2015.01.886

Yuan, R., Wang, J., \& Guo, L. li. (2016). The Effect of Sleep Deprivation on Coronary Heart Disease. Chinese Medical Sciences Journal, 31(4), 247-253. https://doi.org/10.1016/S1001-9294(17)30008-1 
Zakeri, H., Esfahani, B. N., \& Razmjoee, M. (2013). Parenting Styles and Academic Procrastination. Procedia - Social and Behavioral Sciences, 84, 57-60. https://doi.org/10.1016/j.sbspro.2013.06.509

Zm, T. (2011). P-92 Analisis Prokrastinasi Tugas Akhir / Skripsi, (November 2012), 978979.

Zusya, A. R., \& Akmal, S. Z. (2012). Hubungan Self Efficacy Akademik Dengan Prokrastinasi Akademik Pada Mahasiswa Yang Sedang Mengerjakan Skripsi. Jurnal Ilmiah Psikologi 3(2), 191-200. 